\title{
Implementasi Supervisi Pendidikan di SDN 246 Rantebelu Kecamatan Larompong Kabupaten Luwu
}

\author{
Tasdin Tahrim \\ IAIN Palopo, Indonesia \\ Email: tasdin_tahrim@iainpalopo.ac.id
}

Firman Patawari

IAIN Palopo, Indonesia

Email:firman_patawari@iainpalopo.ac.id

\author{
Ali Nahruddin Tanal \\ IAIN Palopo, Indonesia \\ Email: alinahruddintanal@iainpalopo.ac.id
}

DOI: https://doi.org/10.21154/ sajiem.v2i2.52

\begin{abstract}
This study aims to determine the educational supervision plan, educational supervision feedback for the principal or teacher, and the techniques used in educational supervision at SDN 246 Rantebelu Kecamatan Larompong Kabupaten Luwu. The type used in this research is descriptive qualitative. Data collection techniques are interviews, observation, and documentation study. The research subjects were teachers and administrative staff. The results showed that: (1) the education supervision plan carried out at SDN 246 Rantebelu Kecamatan Larompong Kabupaten Luwu is to prepare RPP, syllabus, list of scores, absence of annual programs and semester programs. (2) educational supervision feedback to the principal or teacher, namely verbal (verbal), providing comments on the results of direct observation of the learning process through face-to-face, no distance or equipment used. This method is usually carried out by talking to each other / dialogue, interviews, meetings, speeches, and discussions. Apart from that, giving comments can also be done indirectly through intermediary tools such as telephones,
\end{abstract}


cellphones, etc. because of the distance between the speaker and the interlocutor. Non-verbal (written), providing comments on the results of observations of the learning process by means of writing without direct conversation using short, clear, and understandable language by the recipient. This method can be in the form of correspondence, sms, e-mail, learning photos, and so on. (3) There are 2 types of techniques used in SDN 246 Rantebelu Kecamatan Larompong Kabupaten Luwu, namely direct supervision, which means that the supervisor goes directly to the class to see the learning of students from beginning to end. While administrative supervision is only the administrative aspects that are assessed.

Keywords: educational supervision

\section{Pendahuluan}

Pendidikan merupakan suatu sistem kerja yang saling terkait antara komponen yang satu dengan lainnya. Upaya untuk melaksanakan pencapaiannya yakni mencapai tujuan pendidikan yang dikehendaki. Hal tersebut harus di ikuti dengan prinsip-prinsip yang telah dikembangkan serta teruji kebenarannya. Dalam peningkatan mutu dan relevansi pendidikan adalah tantangan yang paling penting dalam pembangunan pendidikan. Dalam pengelolaan dan penataan manajemen pendidikan, tantangan yang dihadapi adalah bagaimana melakukan pembaharuan organisasi dan manajemen pendidikan dalam rangka efisiensi dan efektifitas, serta otonomi pengelolaan pendidikan. Dalam pengelolaan tersebut yang secara langsung maupun tidak langsung dilakukan oleh seseorang yang saling tergabung didalam lingkungan organisasi tersebut, terkadang disini banyak yang tidak menyadari akan tugas dan fungsinya. Dalam kondisi atau keadaan seperti ini tentunya dibutuhkan suatu perubahan agar dapat mewujudkan tujuan yang diinginkan.

Dalam melakukan proses perubahan sikap dari manusia tersebut yang secara langsung dipengaruhi oleh manusia lain itu sebenarnya memerlukan suatu pengkajian yang cermat dalam pengajaran dan pendidikan yang secara langsung terkait erat dengan kondisi lingkungan sekaligus pengaruh dari figur kepala sekolah yang menjadi atasannya. Di dalam mencapai suatu tujuan tentunya dibutuhkan pula suatu pengawasan yang tujuannya yaitu untuk mencapai suatu ketercapaiaan target melalui evaluasi kinerja bersama. Orang yang menjadi bagian pengawasan ini berada dalam tingkatan tertinggi dan memilki keahlian khusus yang di tunjuk secara langsung untuk datang ke sekolah. Sebutan untuk orangyang melakukan pengawasan tersebut yaitu supervisor yang berasal dari Dinas Pendidikan setempat, yang fungsinya yaitu untuk mengawasi dan menilai sekolah tersebut seperti apa, baik kondisi guru, staf ataupun yang lainnya, yang biasanya didampingi oleh kepala sekolah. dengan adanya pengawasan seperti ini dapat digunakan sebagai evaluasi diri 
sekolah untuk dapat melihat kekurangan-kekurangan apa saja yang telah terjadi atau yang ada di sekolah.

Supervisi pendidikan merupakan disiplin ilmu yang memfokuskan diri pada pengkajian peningkatan situasi belajar mengajar, memberdayakan guru dan mempertinggi kualitas mengajar. Supervisi pendidikan ini menaungi pengawasan semuanya baik dari segi supervisi akademik, supervisi administrasi ataupun supervisi lembaga. Supervisi di era sekarang ini sangat dibutuhkan keberadaannya karena merupakan jaminan mutu (QA), sebagai pendorong mutu untuk sekolah, sebagai transparansi bagi siswa dan orang tua atau masyarakat, dapat mendorong terjadinya proses perbaikan mutu internal secara berkelanjutan, serta menjadi akuntabilitas pendidikan kepada masyarakat. Dan ketika supervisor sudah terjun ke lapangan untuk mengawasi dan mengamati kemudian diberikan feedback. Ini merupakan bentuk tindak lanjut yang diberikan oleh supervisor kepada orang atau pihak yang disupervisi. Disini diharapkan setelah adanya feedback pihak yang disupervisi dapat berubah untuk mengembangkan kemampuannya lebih baik dan lebih sempurna kembali.

\section{Metode Penelitian}

Penelitian ini menggunakan metode deskriptif dengan pendekatan kualitatif, yaitu mendeskripsikan dan menganalisis pelaksanaan supervisi pendidikan di SDN 246 Rantebelu Kecamatan Larompong Kabupaten Luwu yang digunakan yaitu pendekatan kualitatif, di mana data-data yang dikumpulkan dituangkan dalam bentuk uraian.

Metode deskriptif yang digunakan dalam penelitian ini adalah deskriptif kualitatif yang ditujukan untuk mengkaji berbagai permasalahan yang ada di lapangan dan memperoleh makna yang lebih sesuai kondisi lingkungan tempat dilakukannya penelitian.

Senada dengan penjelasan Menurut Sugiyono ${ }^{1}$ menyatakan bahwa metode deskriptif adalah suatu metode yang digunakan untuk menggambarkan atau menganalisis suatu hasil penelitian tetapi tidak digunakan untuk membuat kesimpulan yang lebih luas.. Menurut Nazir ${ }^{2}$ yaitu penelitian deskriptif adalah suatu metode dalam status kelompok manusia, suatu objek, suatu set kondisi, suatu sistem pemikiran, ataupun suatu kelas peristiwa pada masa sekarang, tujuan dari penelitian deskriptif ini adalah untuk membuat deskripsi, gambaran atau lukisan secara sistematis, faktual dan ukuran mengenai fakta-fakta, sifat-sifat serta hubungan antara fenomena yang diselidiki.

${ }^{1}$ Sugiyono. Metode Penelitian Pendidikan: Pendekatan Kuantitatif, Kualitatif, dan R\&D. Bandung: Alfabeta, 2012.

2 Nazir, Moh. Metode Penelitian. Bogor: Ghalia Indonesia. Tim Dosen Administrasi Pendidikan UPI Terbitan: CV Alfabeta, 2012. 
Dapat dikatakan bahwa penelitian deskriptif merupakan penelitian yang berusaha mendeskripsikan suatu gejala, peristiwa yang terjadi pada saat sekarang atau masalah aktual. Secara historis, dilakukan dengan cara deskripsi dalam bentuk kata-kata dan bahasa, pada satu konteks khusus yang alamiah dilakukan dengan memanfaatkan berbagai metode alamiah. Selanjutnya untuk memperoleh data dan temuan penelitian yang otentik, penulis menggunakan pendekatan kualitatif.

Dalam tafsiran Sugiyono ${ }^{3}$ mengemukakan bahwa penelitian kualitatif sering disebut metode naturalistik karena penelitiannya dilakukan pada kondisi yang alamiah (natural setting), disebut juga sebagai metode etnografi, karena pada awalnya metode ini lebih banyak digunakan untuk penelitian bidang antropologi budaya, disebut pula metode kualitatif karena data yang terkumpul dan analisisnya lebih bersifat kualitatif. objek penelitiannya sangat alamiah dengan data yang berkembang apa adanya, tidak dimanipulasi oleh peneliti dan kehadiran peneliti tidak begitu mempengaruhi dinamika pada objek tersebut.

Dalam menemukan data yang benar tentang pelaksanaan menganalisis pelaksanaan supervisi pendidikan di SDN 246 Rantebelu Kecamatan Larompong Kabupaten Luwu, peneliti menggunakan teknik pengumpulan data melalui observasi, wawancara dan studi dokumentasi. Selanjutnya untuk menganalisis data yang telah dikumpulkan sejak awal penelitian sampai akhir penelitian dengan teknik reduksi data, penyajian data dan kesimpulan.

\section{Pembahasan}

Rencana Supervisi Pendidikan di SDN 246 Rantebelu Kecamatan Larompong Kabupaten Luwu yaitu dilaksanakan secara terarah dengan baik sesuai tata aturan yang berlaku dalam kepengawasan diantaranya hal itu dilakukan mulai dari perencanaan hingga mendapatkan hasil yang optimal.

1. Perencanaan Supervisi

Dalam panduan kerja pengawas di jelaskan bahwa program pengawasan berisi program yang spesifik, dapat diukur ketercapaiannya, sesuai dengan kondisi sekolah/madrasah binaan, jelas waktu pelaksanaannya dapat dinilai secara objektif. Esensi penyusunan program kerja pengawas tersebut harus bersifat: Specific and Motivated, Measureable, Achieveable, Realistic, Time Bound, Evaluated, and Reviewed. (SMARTER).

Penyusunan program pengawasan merupakan kegiatan pengawas sekolah dalam menyusun program pengawasan akademik dan manajerial, program pembinaan guru dan/atau kepala sekolah, program pemantauan pelaksanaan Standat Nasional Pendidikan dan program penilaian kinerja

${ }^{3}$ Sugiyono. Metode Penelitian Pendidikan: Pendekatan Kuantitatif, Kualitatif, dan R\&D. Bandung: Alfabeta, 2012. 
guru, dan/atau kepala sekolah, program bimbingan dan pelatihan guru dan/atau kepala sekolah. Program kerja pengawas di kenal ada dua yaitu program tahunan dan program semester. Program pengawas sekolah disusun berdasarkan analisis hasil pengawasan tahun lalu dan kebijakan pendidikan yang berlaku saat ini, seperti terjadinya perubahan peraturan-peraturan pendidikan.

Wilayah atau aspek pengawasan yang dijadikan sasaran dalam menyusun perencanaan meliputi:

a. Pembinaan

Ruang lingkup wilayah atau aspek pembinaan yang dilaksanakan pengawas kepada guru yaitu: 1) Menyusun draf administrasi perencanaan pembelajaran/program bimbingan; 2) Melaksanakan proses pembelajaran/bimbingan 3) Melaksanakan penilaian hasil belajar peserta didik. 4) Membuat dan menggunakan media dan sumber belajar 5) Membimbing dan melatih peserta didik. 6) Menggunakan teknologi informasi dan komunikasi dalam proses pembelajaran. 7) Memanfaatkan hasil penilaian untuk perbaikan mutu pendidikan dan pembelajaran/pembimbingan. 8) Memberikan bimbingan kepada guru untuk melakukan refleksi hasilhasil yang dicapainya. Target pembinaan yang ingin dicapai adalah: 1) Meningkatnya kompetensi guru (kepribadian, pedagogik, profesional, sosial) dan tugas pokok guru. 2) Meningkatnya kemampuan guru dalam mengimplementasikan SNP (isi, proses, kompetensi lulusan, penilaian), 3) Meningkatnya kemampuan guru dalam menyusun silabus, RPP, penilaian, bahan ajar dan penulisan butir soal. 4) Meningkatnya kemampuan guru dalam menyusun Penelitian Tindakan Kelas (PTK).

b. Pemantauan

Ruang lingkup wilayah pemantauan yang dilakukan oleh pengawas kepada guru yaitu pelaksanaan Standar Nasional Pendidikan (SNP) yang meliputi standar isi, standar kompetensi lulusan, standar proses, dan standar penilaian.

c. Penilaian

Ruang lingkup penilaian meliputi: 1) Kinerja Guru, meliputi: a) Merencanakan pembelajaran; b) Melaksanakan pembelajaran; c) Menilai hasil pembelajaran; d) Membimbing dan melatih peserta didik, dan e) Melaksanakan tugas tambahan yang melekat pada pelaksanaan kegiatan pokok sesuai dengan beban kerja guru 2) Metode pemantauan dan pemikiran.

d. Pembimbingan dan Pelatihan Guru

Ruang lingkup pembimbingan dan pelatihan guru dilakukan dengan langkah-langkah sebagai berikut: 1) Tahapan, meliputi: a) Menyusun program pembimbingan dan pelatihan guru, b) 
Melaksanakan pembimbingan dan pelatihan guru dan c) Mengevaluasi hasil pembimbingan dan pelatihan guru. 2) Aspek, meliputi: a) Program Perencanaan Pembelajaran, b) Pelaksanaan Pembelajaran, c) Pelaksanaan Penilaian Hasil Pembelajaran, d) Pelaksanaan Pembimbingan dan pelatihan siswa dan tugas tambahan dan e) Pembimbingan pembuatan KTI dalam bentuk PTK. 3) Waktu: paling sedikit 3 kali dalam satu semester/6 kali dalam setahun dan dilaksanakan terjadwal baik waktu maupun jumlah jam yang diperlukan untuk setiap kegiatan sesuai dengan tema atau jenis keterampilan dan kompetensi guru yang akan ditingkatkan. 4) Tempat: KKG/MGMP/MGP 5) Metode: Bimbingan teknis, pendampingan, workshop, seminar, dan Focus Group Discussion (FGD), yang ditindaklanjuti dengan supervisi akademik.

2. Rencana Pengawasan Akademik

Perencanaan supervisi akademik adalah suatu rencana yang disusun pengawas berbentuk kegiatan pembinaan dengan memberikan bimbingan teknis kepada guru dalam memlaksanakan proses pembelajaran, yang bertujuan meningkatkan kemampuan profesional guru dan meningkatkan kualitas pembelajaran. Perencanaan supervisi akademik merupakan bagian dari progam kerja semester atau tahunan pangawas. Sedangkan kegiatan supervisi akademik merupkan kegiatan supervisi tatap muka pengawas sekolah dengan guru binaan secara individu dalam upaya memberikan bantuan dan bimbingan untuk meningkatkan kemampuan guru, dan sebaiknya dengan menggunakan supervisi klnis. Pelaksnaan supervisi akademik melalui tahapan praobservasi, observasi pembelajaran, pasca observasi.

3. Umpan Balik Supervisi Pendidikan bagi Kepala Sekolah atau Guru di SDN 246 Rantebelu Kecamatan Larompong Kabupaten Luwu.

Umpan balik pada hakikatnya merupakan komentar terhadap suatu hasil pekerjaan dalam hal ini adalah proses pembelajaran yang dapat dilakukan secara tertulis ataupun lisan yang langsung kepada guru tanpa membedakan suku, agama, ras, golongan, jenis kelamin, status sosial ekonomi, dan yang berkebutuhan khusus. Umpan balik diberikan sedemikian sehingga guru dapat memahami temuan, mengubah perilaku yang teridentifikasi dan mempraktekkan panduan yang diberikan.

Dari umpan balik pengawas dan dukungan pada guru, maka dapat ditentukan bersama :

a. Perilaku positif pembelajaran yang harus dipelihara

b. Strategi-strategi alternatif untuk mencapai perubahan yang diinginkan.

c. Kelayakan/kepantasan dari menggunakan kembali metode yang pernah dilakukan. 
Asumsinya adalah apabila perilaku guru berubah, maka permasalahan spesifik dalam bidang yang menjadi perhatian akan dapat diselesaikan. Secara umum ada 2 metode pemberian umpan balik yang efektif, yakni:

a. Verbal (lisan)

Pemberian komentar terhadap hasil pengamatan proses pembelajaran secara langsung melalui tatap muka tidak ada jarak atau peralatan yang digunakan. Metode ini biasanya dilakukan dengan cara saling berbicara/berdialog, wawancara, rapat, pidato, dan diskusi. Selain itu pemberian komentar juga dapat dilakukan secara tidak langsung melalui perantara alat seperti telepon, handphone, dan lain sebagainya karena adanya jarak si pembicara dengan lawan bicara.

b. Non verbal (tertulis)

Pemberian komentar terhadap hasil pengamatan proses pembelajaran dengan perantaraan tulisan tanpa adanya pembicaraan secara langsung dengan menggunakan bahasa yang singkat, jelas, dan dapat dimengerti oleh penerima. Metode ini dapat berupa suratmenyurat, sms, e-mail, foto pembelajaran, dan lain sebagainya.

Umpan balik adalah upaya untuk memberi pertolongan bagi supervisor dalam melaksanakan tindak lanjut supervisi. Dari umpan balik itu pula dapat tercipta suasana komunikasi yang tidak menimbulkan ketegangan, menonjolkan otoritas yang mereka miliki, memberi kesempatan untuk mendorong guru memperbaiki penampilan, serta kinerjanya.

Setiap guru, apapun latar belakang dan status sosialnya (jenis kelamin, status sosial ekonomi, agama, suku, dan yang berkebutuhan khusus) harus mendapatkan layanan umpan balik yang sama. Umpan balik diberikan sedemikian rupa sehingga guru dapat memahami temuan, mengubah perilaku yang teridentifikasi dan mempraktekkan panduan yang diberikan.

4. Teknik yang Digunakan dalam Supervisi Pendidikan Di SDN 246

Rantebelu Kecamatan Larompong Kabupaten Luwu.

Supervisi atau pengawasan yang baik perlu menggunakan cara-cara yang baik. Cara dalam konteks supervisi dikenal dengan istilah metode. Metode dalam supervisi adalah suatu cara yang ditempuh oleh seorang supervisor pendidikan guna merumuskan tujuan yang hendak dicapai baik oleh sistem perorangan maupun kelembagaan pendidikan itu sendiri. Sedangkan teknik adalah langkah-langkah konkrit yang dilakukan oleh seorang supervisor. Teknik yang dilaksanakan dalam supervisi dapat ditempuh melalui berbagai cara, yakni pada prinsip supervisi berusaha merumuskan harapan-harapan menjadi sebuah kenyataan. 
Teknik supervisi merupakan cara-cara yang ditempuh supervisor untuk mencapai tujuan tertentu baik yang berhubungan dengan penyelesaian masalah manajerial dengan sasaran kepala sekolah dalam mengembangkan kelembagaan serta masalah-masalah lain yang berhubungan dengan serta berorientasi pada peningkatan mutu pendidikan dan masalah akademik dengan sasaran para guru kelas dan mata pelajaran untuk memperbaiki proses pembelajaran dikelas, dilaboratorium dan di alam bebas serta memperbaiki pencapaian hasil belajar peserta didik.

Dengan demikian supervisi yang baik perlu menggunakan metode dan teknik yang dapat memudahkan seorang supervisor dalam melaksanakan tugasnya dan tujuan apa yang hendak disupervisi tercapai dengan baik. Metode dalam supervisi terbagi menjadi dua, yakni metode langsung (direct method) dan metode tak langsung.

a. Metode Langsung (direct method)

Metode langsung dalam supervisi pendidikan merupakan cara pendekatan langsung terhadap sasaran supervisi. Metode ini merupakan suatu cara yang dilakukan oleh supervisor yang secara pribadi dan langsung berhadapan dengan orang yang disupervisi, baik secara perorangan maupun secara kelompok. Contoh nya observasi kelas, pertemuan individual, rapat guru dan sebagainya.

b. Metode Tidak Langsung

Metode ini dilakukan oleh seorang supervisor secara tidak langsung akan tetapi melalui media (alat) komunikasi. Supervisor tidak secara langsung menghadapi atau berhadapan dengan orangorang yang disupervisi tetapi menggunakan berbagai alat atau media komunikasi. Umiarso dan Imam Gojali membagi pendekatan dalam supervisi menjadi tiga bagian. Pertama, pendekatan direktif adalah cara pendekatan terhadap masalah yang bersifat langsung. Supervisor memberikan arahan langsung, yakni menjelaskan, memberi contoh, menetapkan tolak ukur, dan menguatkan. Kedua, pendekatan tidak langsung (non direktif) yakni cara pendekatan terhadap permasalahan yang sifatnya tidak langsung. Supervisor tidak secara langsung menunjukkan permasalahan tetapi, ia terlibat terlebih dahulu mendengarkan secara aktif apa yang dikemukakan oleh guru-guru.

Prilaku supervisor adalah mendengarkan, memberanikan, menjelaskan, menyajikan, dan memecahkan masalah. Ketiga, pendekatan kolaborasi adalah cara pendekatan yang memadukan cara pendekatan direktif dan non direktif menjadi pendekatan baru. Pada pendekatan ini baik supervisor maupun guru-guru bersama-sama dan bersepakat untuk menetapkan struktur, proses, dan kriteria dalam melaksanakan proses percakapan masalah yang dihadapi guru. Prilaku 
supervisor adalah menyajikan, menjelaskan, mendengarkan, memecahkan masalah, dan negosiasi.

Teknik-teknik dalam supervisi secara garis besar terbagi menjadi dua, yaitu teknik perseorangan dan teknik kelompok.

a. Teknik Perseorangan

Menurut Amatembun teknik perseorangan dalam supervisi pendidikan digunakan bila orang yang disupervisi dihadapi secara tersendiri (individual) biasanya dilakukan terhadap individu yang mengalami masalah khusus atau bersifat pribadi. Menurut Ngalim Purwanto teknik perseorangan adalah supervisi yang dilakukan secara perseorangan. Beberapa kegiatan yang dapat dilakukan antara lain sebagai berikut :

1) Mengadakan kunjungan kelas (clasroom visition).

2) Mengadakan kunjungan observasi (observasi visit).

3) Membinmbing guru tentang cara-cara mempelajari siswa dan mengatasi problema yang dihadapi siswa.

4) Membimbing guru-guru dalam hal-hal yang berhubungan dengan pelaksanaan kurikulum sekolah :

a) Menyusun program-program semester.

b) Menyusun atau membuat program satuan pelajaran.

c) Mengorganisasikan kegiatan-kegiatan pengelolaan kelas.

d) Melaksanakan teknik-teknik evaluasi pengajaran.

e) Menggunakan media dan sumber dalam proses belajarmengajar.

f) Mengorganisasikan kegiatan-kegiatan siswa dalam bidang ekstrakurikuler, study tour, dan sebagainya.

b. Teknik Kelompok

Teknik kelompok dalam supervisi pendidikan adalah cara pelaksanaan supervisi terhadap sekelompok orang yang disupervisi. Orang-orang yang diduga mempunyai masalah yang sama dapat dihadapi secara bersama-sama dalam situasi supervisi oleh supervisor. Misalnya dalam rapat guru, lokakarya, sebagainya.

Beberapa kegiatan yang dapat dilakukan supervisor dalam melaksanakan teknik ini adalah:

1) Mengadakan pertemuan atau rapat (meetings).

2) Mengadakan diskusi kelompok (group discussions).

3) Mengadakan penataran-penataran (inservice-training).

Selain metode dan teknik di atas seorang supervisor dalam melaksanakan tugas dan fungsinya secara baik (efektif dan efisien), seorang supervisor pendidikan perlu memiliki "skill" 
(keterampilan-keterampilan) tertentu sekurang-kurangnya supervisor perlu memiliki keterampilan dalam kepemimpinan, proses kelompok, hubungan insani, administrasi personil dan evaluasi pendidikan.

a) Keterampilan dalam kepemimpinan

Kepemimpinan (leadhership) menyangkut dua aspek bipolar yaitu pemimpin dan yang dipimpin. Kepemimpinan yang baik bila terjalin suatu interaksi yang harmonis anatara kedua unsur itu. Dalam proses kepemimpinan ini seorang supervisor sebagai pemimpin pendidikan, mungkin menempuh cara-cara sebagai berikut:

1) "working on" bekerja diatas. Yaitu supervisor yang menganggap fungsinya sebagai penguasa yang mengusai (mendominir), memerintah, mengarahkan bawahannya. Supervisor memperlihatkan power over (kekuasaan atas) orang-orang yang disupervisinya.

2) "working for" bekerja bagi. Yaitu supervisor yang menganggap bahwa fungsinya ialah sebagai pembantu bagi orang-orang yang disupervisinya untuk mewujudkan tujuan-tujuan dari orang-orang yang disupervisinya. Supervisor yang demikian mempunyai daya kerja keras bagi kepentingan orang-orang yang disupervisinya, yang disupervisi merasa keenakan karena segala sesuatu telah dipersiapkan dan dikerjakan sendiri oleh supervisornya.

3) "working within" bekerja bersama dengan orang-orang yang disupervisi. Supervisor yang demikian menganggap bahwa fungsinya adalah membina orang-orang yang disupervisi untuk menentukan dan melaksanakan tujuan bersama yang telah ditetapkan.

Dari penjelasan diatas bahwa keterampilan dalam kepemimpinan, seorang supervisor pendidikan menempatkan posisinya sebagai atasan yang siap untuk mengarahkan, memerintahkan atau menginstruksikan bawahannya dengan aturan-aturan yang telah dibuat. Supervisor juga menempatkan posisinya sebagai pembantu bagi orang-orang yang disupervisinya dalam mewujudkan tujuan yang ingin dicapai. Disamping itu supervisor pendidikan juga menempatkan posisinya sebagai mitra yang siap bekerja bersama-sama dengan orang yang disupervisi dalam mencapai tujuan yang diinginkan.

b) Keterampilan dalam proses kelompok 
Pemimpin dan yang dipimpin merupakan satu kesatuan yang saling bergantungan (interdepensi). Adanya pemimpin karena ada sekelompok orang-orang yang dipimpinnya. Seorang supervisor sebagai pemimpin pendidikan harus dapat menciptakan situasi dimana dia dan orang-orang yang disupervisi dapat bekerja secara bergotomg royong (kooperatif). Dalam hal ini supervisor yang baik di alam proses kelompok setidaknya mencakup beberapa hal sebagai berikut :

1) Membangkitkan semangat kerja sama dalam kelompok.

2) Merumuskan bersama tujuan yang akan dicapai.

3) Merencanakan bersama.

4) Mengambil keputusan bersama.

5) Menciptakan tanggung jawab bersama.

6) Menilai dan merevisi bersama rencana kearah terwujudnya tujuan yang telah ditetapkan bersama dan sebagainya

Disamping itu supervisor juga perlu melibatkan orangorang yang berkepentingan dalam pendidikan. Dalam hal ini supervisor perlu membekali dirinya dengan berbagai teknikteknik komunikasi yang dapat digunakan untuk melaksanakan supervisinya.

c) Keterampilan dalam hubungan insani

Keterampilan dalam hubungan manusia (human relations) merupakan keterampilan penting bagi supervisor, sebab dalam melaksanakan fungsi dan tugasnya seorang supervisor berhubungan secara langsung atau tidak langsung, baik hubungan vertikal atau horizontal, baik sepihak maupun timbal balik dengan orang-orang yang disupervisi. Hubungan insani dapat dibedakan menjadi :

1) Hubungan pribadi

Pribadi dalam hal ini menjadi perhatian utama. Berkat terjalinnya hubungan yang baik antar pribadi seseorang dapat membuka hati dan bersahabat sehingga dapat saling menerima.

2) Hubungan fungsional

Hubungan ini berkaitan dengan dan tugas yang dilaksanakan oleh seseorang. Hubungan ini juga disebut dengan hubungan profesional yaitu hubungan dalam menunaikan profesinya (jabatan) yang diemban oleh seseorang. 
3) Hubungan instrumental

Hubungan ini didasarkan pada "memperalat" bawahan. Bahwa orang-orang yang disupervisi kadang-kadang dianggap hanya sebagai alat untuk memenuhi keinginan supervisor.

4) Hubungan konvensional

Hubungan ini diidasarkan atas kebiasaan atau konvensi yang berlaku. Hubungan ini disebut juga dengan hubungan tradisional yaitu berdasarkan tradisi atau adat kebiasaan yang berlaku, misalnya bawahan wajar memberi hormat kepada atasan. Penghargaan terhadap pribadi dalam hubungan ini menjadi perhatian penting. Penghargaan terhadap pribadi yang disupervisi oleh supervisor tampak pada:

a) Memperhatikan mereka dan masalah-masalahnya.

b) Bersedia melayani kepentingan mereka.

c) Memberikan perhatian terhadap gagasan dan saran-saran mereka.

d) Mendorong kegiatan-kegiatan sosial guna terjalin relasi-relasi yang akrab diantara mereka.

e) Menciptakan kondisi-kondisi kerja yang menarik dan memuaskan.

f) Mengadakan pertemuan-pertemuan yang memungkinkan mereka bertukar pendapat dan sebagainya.

d) Keterampilan dalam administrasi personil

Keterampilan ini berkaitan dengan keahlian seorang supervisor dalam menempatkan seseorang pada posisi yang tepat (in the right man in the right place). Supervisor perlu memiliki keterampilan dalam bidang administrasi personil. Administrasi personil (personil administrasion) pembinaan dan pemanfaatan secara maksimal potensi-potensi orangorang dalam staf. Orang-orang yang terlibat dalam administrasi personil adalah kepala sekolah, guru-guru atau staf pengajar baik tetap maupun tidak tetap, staf bukan pengajar (tenaga administratif) seperti para karyawan tata usaha sekolah, penjaga sekolah dan murid-murid.

e) Keterampilan dalam evaluasi

Seorang supervisor perlu memiliki keterampilan dalam menggunakan prosedur dan teknik-teknik evaluasi pendidikan. Evaluasi mengandung keterampilan dalam : 
1) Merumuskan tujuan kriteria-kriteria guna mempertimbangkan berbagai perubahan.

2) Mengumpulkan fakta-fakta perubahan.

3) Menetapkan kriteria-kriteria dalam menyusun pertimbangan-pertimbangan mengenai perubhan secara wajar.

4) Merevisi rencana-rencana yang telah disusun.

Supervisor hendaklah membina orang-orang yang disupervisinya untuk menilai aktivitas-aktivitas mereka, serta mengambil keputusan-keputusan guna memperbaiki prosesproses kelompok.

\section{Kesimpulan}

Supervisi ialah pembinaan yang diberikan kepada seluruh staf sekolah agar mereka dapat meningkatkan kemampuan untuk mengembangkan situasi belajar-mengajar yang lebih baik. Orang yang melakukan supervisi disebut dengan supervisor. Supervisi dapat kita artikan sebagai pembinaan. Sedangkan sasaran pembinaan tersebut bisa untuk kepala sekolah, guru, pegawai tata usaha. Namun yang menjadi sasaran supervisi diartikan pula pembinaan guru.

Tujuan supervisi pendidikan ialah mengembangkan situasi belajar mengajar yang lebih baik melalui pembinaan dan peningkatan profesi mengajar. Fungsi dan tujuan supervisi pendidikan diantaranya adalah Sebagai arah pendidikan,tujuan sebagai titik akhir, tujuan sebagai titik pangkal mencapai tujuan lain. Dalam hal ini, tujuan pendidikan yang satu dengan yang lain merupakan satu kesatuan yang tak terpisahkan.

Supervisi memiliki tujuan yang sangat penting untuk dicapai, oleh karena itu supervisi tentunya memiliki manfaat yang sangat penting. Diantara manfaat supervisi adalah Mengkoordinasi semua usaha sekolah, Memperlengkapi kepemimpinan sekolah, Memperluas pengalaman guru, Menstimukasi usaha-usaha sekolah yang kreatif, Memberi fasilitas dan penilaian yang terus menerus dan masih banyak lagi manfaat atau fungsi supervisi pendidikan tersebut. Selain memiliki tujuan dan fungsi, supervisi juga memiliki prinsip dasar dalam proses pelaksanaannya. Kemudian supervisi juga memiliki berbagi tipe, diantarannya adalah otokrasi, demokratis, demokratis semu, manipulasi diplomasi badan Laissez-faire.

\section{Daftar Pustaka}

Aqib, Zainal dan Rohmanto, Elham. Membangun Profesionalisme Guru dan Pengawas Sekolah. Surabaya: Yrama Widya Ismail, 2007. 
Danim, Sudarwan dan Danim, Yunan. Administrasi Sekolah dan Manajemen Kelas: Strategi Membangun Disiplin Kelas dan Suasana Edukatif di Sekolah. Bandung: Pustaka Setia, 2011.

Fathurrohman, Pupuh dan Suryana, AA. Supervisi Pendidikan dalam Pengembangan Proses Pendidikan. Bandung: Refika Aditama, 2011.

Mantja,W.,Profesionalisasi Tenaga Kependidikan: Manajemen Pendidikan dan Supervisi Pengajaran. Malang: ElangMas, 2007.

Mulyasa, Enco. Standar Kompetensi dan Sertifikasi Guru. Bandung: Remaja Rosdakarya, 2009.

Muslim, Sri Banun. Supervisi Pendidikan Meningkatkan Kualitas Profesionalisme Guru, Bandung: Alfabeta, 2013.

Nazir, Moh. Metode Penelitian. Bogor: Ghalia Indonesia. Tim Dosen Administrasi Pendidikan UPI Terbitan: CV Alfabeta, 2012.

Purwanto, M. Ngalim. Prinsip-Prinsip dan Teknik Evaluasi Pendidikan. Bandung: Remaja Rosdakarya, 2009.

Sagala, Syaiful. Administrasi Pendidikan Kontemporer. Bandung: Alfabeta, 2012.

Sahertian, Piet A. Konsep Dasar dan Teknik Supervisi Pendidikan dalam Rangka Pengembangan Sumber Daya Manusia. Jakarta: Rineka Cipta, 2010.

Sudjana, Nana. Dasar-Dasar Proses Belajar Mengajar. Bandung: Sinar Baru Algesindo, 2011.

Sugiyono. Metode Penelitian Pendidikan: Pendekatan Kuantitatif, Kualitatif, dan R\&D. Bandung: Alfabeta, 2012. 